\title{
HUBUNGAN TINGKAT PENGETAHUAN WARGA TENTANG DEMAM BERDARAH DENGAN UPAYA PENCEGAHAN DEMAM BERDARAH DI DUKUH GUNUNG RT 01 RW 12 DESA PUCANGAN KECAMATAN KARTASURAKABUPATEN SUKOHARJO
}

Budi Herminto ${ }^{1}$, Diyono ${ }^{2}$, Windra Kusumaningtyas ${ }^{3}$

\begin{abstract}
Background: Indonesia has a high risk of contracting dengue fever because it has spread to all regions. Dengue fever (DHF) is an infectious disease caused by dengue virus with the clinical manifestations of fever characterized by shock. The DHF cases is still occurred on Dukuh Gunung in Pucangan Kartasura Sukoharjo, it is caused the $3 \mathrm{M}$ plus program has not been implemented optimally and there has not been a study record how is the level of the villagers knowledge about the dengue disease.

Objective: To determine the relationship between the level of the villagers knowledge about the dengue disease with the dengue fever prevention efforts on Dukuh Gunung Villagers of RT 01, RW 12 in Pucangan Kartasura, Sukoharjo.

Research's Design: This study is analytical research, designed by correlation and cross sectional approach. The study population was the head of all families in Dukuh Gunung RT 01, RW 12, Pucangan, Kartasura, Sukoharjo. Sample amount of 66 head of families. The sampling technique is random sampling. Datas were analyzed by chi square with SPSS 18.

Research's Result: (1) The average value of the villagers knowledge about the dengue fever is high category. (2) The average value of the dengue prevention efforts is good category. (3) The result of chi square test with $p$ obtained 0,004 so, $p<0,05$.

Research's conclusion: There is a significant relationship between the level of the villagers knowledge about the dengue disease with the dengue fever prevention efforts on Dukuh Gunung Villagers of RT 01, RW 12 Pucangan, Kartasura, Sukoharjo.
\end{abstract}

Keyword :The levels of knowledge, The dengue fever, Prevention efforts

\section{PENDAHULUAN}

Demam berdarah atau Dengue Fever (DF) dan demam berdarah dengue/DBD (dengue haemorrhagic fever/DHF) adalah penyakit infeksi yang disebabkan oleh virus dengue dengan manifestasi klinis demam, nyeri otot dan/atau nyeri sendi yang disertai lekopenia, ruam, limfadenopati, trombositopenia dan diatesis hemoragik. Pada DBD terjadi perbesaran plasma yang ditandai oleh hemokonsentrasi (peningkatan hematokrit) atau penumpukan cairan di rongga tubuh. Sindrom renjatan dengue (dengue shock syndrome) adalah demam berdarah dengue yang di tandai oleh renjatan/syock. (Sudoyo, et al., ed, 2007) 
Indonesia mempunyai resiko besar untuk terjangkit penyakit demam berdarah dengue karena virus Dengue dan nyamuk penularnya yaitu Aedes Aegypti tersebar luas di seluruh daerah-daerah pedesaan maupun perkotaan, baik di rumahrumah maupun di tempat-tempat umum, kecuali daerah yang ketinggiannya lebih dari 1.000 meter dari permukaan air laut. Iklim tropis juga mendukung berkembangnya penyakit ini, lingkungan fisik seperti curah hujan yang menyebabkan tingkat kelembaban tinggi, merupakan tempat potensial berkembangnya penyakit ini. Nyamuk ini berkembang biak di tempat-tempat penampungan air atau tandon, seperti bak kamar mandi, drum, tempayan dan barang bekas yang dapat menampung air hujan baik di rumah, sekolah, dan tempat umum lainnya. (Depkes RI, 2006)

Provinsi Jawa Tengah merupakan salah satu daerah yang rawan terjangkit penyakit ini, hal ini dapat dilihat dari angka kejadian kasus demam berdarah dengue yang terjadi dari tahun ke tahun terus meningkat. Dari data Dinas Kesehatan Provinsi Jawa Tengah, didapat angka kasus kejadian demam berdarah dengue di Jawa Tengah pada tahun 2007 mencapai angka 20.391 kasus dengan 327 angka kematian (IR $=6,2$ dan CFR $=$ $1,6 \%$ ). Hal ini berbeda dibandingan dengan tahun-tahun sebelumnya, pada tahun 2006 jumlah kasus kejadian hanya 10.924 kasus dengan 220 angka kematian (IR = 3,39 dan $\mathrm{CFR}=2,01 \%$ ), pada tahun 2005 jumlah kasus kejadian hanya 7.144 kasus dengan 181 angka kematian (IR $=2,17$ dan CFR $=2,53$ $\%)$, pada tahun 2004 jumlah kasus kejadian hanya 9.742 kasus dengan 169 angka kematian (IR = 3,00 dan $\mathrm{CFR}=1,73 \%$ ), pada tahun 2003 jumlah kasus kejadian hanya 8.670 kasus dengan 153 angka kematian
(IR $=2,70$ dan CFR $=1,76 \%$ ). Dari data diatas dapat disimpulkan bahwa angka kejadian tertinggi siklus lima tahunan DBD Jawa Tengah terjadi pada tahun 2007. (Dinkes Prov Jateng, 2006)

Dukuh Gunung RT 01 RW 12 Desa Pucangan, Kartasura adalah desa yang berada di wilayah kerja Puskesmas Kartasura. Di dukuh tersebut jumlah kasus DBD berdasarkan sumber data yang diperoleh dari Puskesmas Kartasura pada tahun 2012 terdapat 15 kasus dengan 1 kasus meninggal.

Dari wawancara awal yang telah dilakukan pada kader kesehatan mengatakan bahwa kebanyakan warga Dukuh Gunung RT 01 RW 12 Desa Pucangan, Kartasura belum melaksanakan program "3M Plus" dengan tepat. Menurut kader tersebut penyebabnya adalah warga kurang aktif melakukan penhberantasan sarang nyamuk. Selama ini juga belum ada data pasti tentang tingkat pengetahuan warga mengenai penyakit DBD.

\section{METODE PENELITIAN}

Penelitian ini merupakan penelitian analitik, dengan desain penelitian korelasi dan pendekatan cross sectional.

Populasi dalam penelitian ini adalah semua kepala keluarga Dukuh Gunung Rt 01/12 Pucangan Kartasura Sukoharjo yang berjumlah 80 orang. Sampel penelitian adalah kepala keluarga Dukuh Gunung RT 01/12 Pucangan Kartasura Sukoharjo yang diambil dengan menggunakan kriteria inklusi dan eksklusi. Adapun besar sampel diambil menggunakan tabel krecjie dan didapatkan sampel sebanyak 66 kepala keluarga.

Dalam penelitian ini, peneliti menggunakan teknik simple random sampling. Data tentang tingkat pengetahuan dan tentang upaya pencegahan Demam Berdarah diperoleh melalui kuesioner. Analisa 
bivariat menggunakan uji Chi Square dengan bantuan SPSS for windows seri 18.

\section{HASIL PENELITIAN}

Pengambilan data dilakukan di Dukuh Gunung RT 01 RW 12 Pucangan Kartasura Sukoharjo pada tanggal 16 sampai 28 Maret 2015. Dari data tentang karakteristik responden, yaitu :

1. Karakteristik responden berdasarkan tingkat pendidikan

Tabel 1. Tingkat Pendidikan Responden

\begin{tabular}{ccc}
\hline $\begin{array}{c}\text { Tingkat } \\
\text { Pendidikan }\end{array}$ & $\mathbf{f}$ & $\%$ \\
\hline SD & 21 & 31,81 \\
\hline SMP & 19 & 28,8 \\
\hline SMA/ SMK & 22 & 33,33 \\
\hline D III & 1 & 1,51 \\
\hline S 1 & 3 & 4,54 \\
\hline Jumlah & 66 & 100 \\
\hline
\end{tabular}

2. Karakteristik responden berdasarkan umur

Tabel 2. Umur Responden

\begin{tabular}{ccc}
\hline Umur & $\mathbf{f}$ & $\%$ \\
\hline $35-40$ & 10 & 15,15 \\
\hline $41-45$ & 15 & 27,72 \\
\hline $46-50$ & 19 & 28,78 \\
\hline $51-55$ & 12 & 18,18 \\
\hline $55-60$ & 10 & 15,15 \\
\hline Jumlah & 66 & 100 \\
\hline
\end{tabular}

Adapun hasil penelitian ini dapat dijabarkan sebagai berikut :

1. Tingkat Pengetahuan

a. Distribusi Frekuensi

Tabel 3. Distribusi Frekuensi Tingkat Pengetahuan

\begin{tabular}{ccc}
\hline $\begin{array}{c}\text { Tingkat } \\
\text { Pengetahuan }\end{array}$ & $\mathbf{f}$ & $\%$ \\
\hline Rendah & 30 & 45,5 \\
\hline Tinggi & 36 & 54,5 \\
\hline Jumlah & 66 & 100 \\
\hline
\end{tabular}

Dari tabel di atas didapatkan data ada 36 responden $(54,5 \%)$ memiliki tingkat pengetahuan tinggi dan 30 responden (45,5\%) memiliki tingkat pengetahuan rendah.

b. Analisa Univariat

Tabel 4. Analisa Univariat Tingkat Pengetahuan

\begin{tabular}{lc}
\hline Mean & 22,77 \\
\hline Median & 27 \\
\hline Modus & 15 \\
\hline Std. Deviasi & 6,6 \\
\hline Range & 16 \\
\hline
\end{tabular}

Berdasarkan tabel 4. didapatkan data mean $=27,77$, median $=$ 27,00 , modus $=15$, Std. Deviasi $=$ 6,635 dan range $=16$.

2. Upaya Pencegahan Demam Berdarah

a. Distribusi frekuensi

Tabel 5. Distribusi Frekuensi Upaya Pencegahan Demam Berdarah

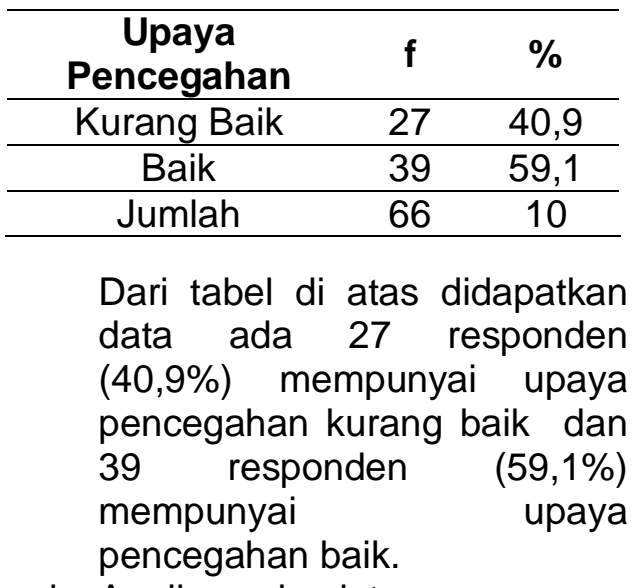

b. Analisa univariat

Tabel 6. Hasil Analisa Univariat Upaya Pencegahan Demam Berdarah

\begin{tabular}{cc}
\hline Mean & 16,44 \\
\hline Median & 18,00 \\
\hline Modus & 10 \\
\hline Std. Deviasi & 12,39 \\
\hline Range & 10 \\
\hline
\end{tabular}


Berdasarkan tabel 6 didapatkan hasil mean $=16,44$, median $=$ 18,00 , modus $=10$, Standar deviasi $=12,395$, range $=10$.

3. Hubungan Tingkat Pengetahuan Warga dengan Upaya Pencegahan Demam Berdarah

Tabel 7. Tabulasi Silang

\begin{tabular}{cccc}
\hline \multirow{2}{*}{$\begin{array}{c}\text { Tingkat } \\
\text { Pengetahuan }\end{array}$} & \multicolumn{3}{c}{ Upaya Pencegahan } \\
\cline { 2 - 4 } & $\begin{array}{c}\text { Kurang } \\
\text { Baik }\end{array}$ & Baik & Jumlah \\
\hline Rendah & 18 & 12 & 30 \\
\hline Tinggi & 9 & 27 & 36 \\
\hline Jumlah & 27 & 39 & 66 \\
\hline
\end{tabular}

Dari tabel di atas terlihat bahwa responden yang tingkat pengetahuan tinggi dengan upaya pencegahan baik ada 27 orang dan yang kurang baik ada 9 orang. Responden yang tingkat pengetahuan rendah dengan upaya pencegahan baik ada 12 orang dan yang kurang baik ada 18 orang,

Hasil Uji Chi Square seperti terlihat pada tabel 8 yaitu :

Tabel 8.Hasil Uji Chi Square

\begin{tabular}{ccccc}
\hline & Value & $\begin{array}{c}\text { Asym } \\
\text { df. Sig. } \\
\mathbf{( 2 -} \\
\text { sided) }\end{array}$ & $\begin{array}{c}\text { Ap } \\
\text { prox } \\
\text { Sig }\end{array}$ \\
\hline $\begin{array}{c}\text { Pearson } \\
\text { Chi-Square }\end{array}$ & $8,292^{\mathrm{a}}$ & 1 & 0,004 & \\
\hline $\begin{array}{c}\text { Contingency } \\
\text { Coefficient }\end{array}$ & 0,334 & & &, 004 \\
\hline
\end{tabular}

Dari tabel di atas dapat dilihat pada Pearson Chi Square yaitu 0,004 (probabilitas < $0,05)$ sehingga $\mathrm{Ha}$ diterima, yang berarti ada hubungan yang signifikan antara tingkat pengetahuan warga dengan upaya pencegahan demam berdarah di Dusun Gunung Rt
01 Rw 12 Desa Pucangan, Kartasura, Sukoharjo.

\section{PEMBAHASAN}

1. Tingkat Pengetahuan

Berdasarkan analisis univariat menghasilkan data sebagai berikut yaitu mean : 27,77 yang berarti rata-rata tingkat pengetahuan warga tinggi, median : 27,00 yang berarti nilai tengah tingkat pengetahuan warga tinggi, modus : 15 yang berarti fenomena yang sering muncul adalah tingkat pengetahuan warga yang tinggi.

Berdasarkan data yang didapat ternyata rata-rata warga Dukuh Gunung berpendidikan SD dan SMP, dan masih berusia produktif antara 46 - 50 th yang berarti masih bisa untuk menerima pendidikan yang diberikan oleh para kader ataupun oleh para penyuluh. Hal ini juga sesuai dengan teori yang dikemukakan oleh Wawan dan Dewi (2010), bahwa pengetahuan itu dapat dipengaruhi oleh pendidikan, karena bimbingan yang diberikan seseorang terhadap perkembangan orang lain akan menentukan orang tersebut untuk berbuat hal yang sesuai. Begitu juga pengetahuan dipengaruhi dengan umur, semakin cukup umur dan tingkat pengetahuan seseorang maka akan lebih matang dalam berfikir dan bekerja.

2. Upaya Pencegahan

Hasil analisis univariat menghasilkan data sebagai berikut yaitu mean : 16,44 yang berarti upaya pencegahan demam berdarah baik, median 18 yang berarti nilai tengah upaya pencegahan demam berdarah baik, modus 10 yang berarti fenomena yang sering muncul dari upaya pencegahan demam 
berdarah adalah upaya pencegahan yang baik.

Dari hasil yang didapat sebagian besar warga sudah melakukan upaya pencegahan dengan baik, dan hal ini dikarenakan warga sudah mempunyai kebiasaan untuk melakukan kerja bakti dan juga membersihkan sampahsampah yang sudah tidak terpakai. Akan lebih bagus lagi jika dilakukan simulasi demam berdarah, karena warga akan cepat mengerti dan meniru apa yang dilakukan oleh kader kesehatan setempat.

Hal ini juga sesuai dengan teori yang dikemukakan oleh Fitriani (2011), pembentukan perilaku dengan kebiasaan yaitu membiasakan diri untuk berperilaku yang sesuai dengan harapan maka akan terbentuk perilaku yang diinginkan, begitu juga pembentukan perilaku dengan menggunakan model warga akan cepat memahami dan mengerti bila ada perilaku yang dicontoh menggunakan model.

Menurut Skiner dalam Notoatmodjo (2011), merumuskan bahwa perilaku merupakan respon atau reaksi seseorang terhadap stimulus (rangsangan dari luar). Oleh karena perilaku ini terjadi melalui proses adanya stimulus terhadap organisme, dan kemudian organisme tersebut merespons, maka teori Skiner ini disebut teori "S-O-R" atau Stimulus Organisme Respons.

3. Hubungan Tingkat Pengetahuan Warga Tentang Demam Berdarah dengan Upaya Pencegahan Demam Berdarah

Berdasarkan analisa bivariat hubungan tingkat pengetahuan warga tentang demam berdarah dengan upaya pencegahan demam berdarah didapatkan hasil bahwa ada hubungan antara tingkat pengetahuan warga tentang demam berdarah dengan upaya pencegahan demam berdarah di Dukuh Gunung RT 01 RW 12 Desa Pucangan, Kartasura, Sukoharjo. Hal ini ditunjukkan dengan nilai Contingency Coefficient sebesar 0,334 atau $33,4 \%$ dan nilai Pearson Chi Square sebesar 0,004 (probabilitas < 0,05) sehingga $\mathrm{Ha}$ diterima. Dari penelitian ini ditemukan 18 responden $(27,27 \%)$ memiliki tingkat pengetahuan rendah dan upaya pencegahan demam berdarah kurang baik. Hal ini sesuai dengan teori menurut Notoatmojo (2011) yang menjelaskan bahwa perilaku yang didasari oleh pengetahuan akan lebih baik daripada perilaku yang tidak didasari oleh pengetahuan. Teori lain yang mendukung hasil penelitian adalah menurut Wawan dan Dewi (2010), yang menyebutkan bahwa dengan pendidikan seseorang akan memperoleh informasi dan pengetahuan baru yang dapat mempengaruhi keputusan yang akan diambil. Dalam hal ini pengetahuan warga tentang demam berdarah akan mempengaruhi upaya yang diambil warga dalam mencegah demam berdarah. Hasil analisa univariat menunjukkan bahwa rata-rata tingkat pengetahuan warga bernilai 27,77 yang termasuk kategori tinggi, sedangkan nilai rata-rata upaya pencegahan bernilai 16,44 yang termasuk kategori baik. Data ini memberikan bukti empiris apabila pengetahuan orang secara umum itu baik (tinggi) maka akan memberikan tindakan/perilaku yang baik pula.

Dari data tabulasi silang diperoleh 27 responden $(40,90 \%)$ memiliki tingkat pengetahuan tinggi dan mempunyai upaya pencegahan 
demam berdarah yang baik. Hal ini sesuai dengan teori bahwa pengetahuan atau kognitif merupakan domain yang sangat penting dalam membentuk tindakan seseorang (over behaviour). (Notoatmodjo, 2011) Sehingga responden yang memiliki pengetahuan tinggi tentang demam berdarah dapat melakukan upaya pencegahan penyakit demam berdarah secara baik.

Hasil penelitian juga sesuai dengan penelitian terdahulu yang diteliti oleh Kustyaningrum (2006) dimana pada penelitian tersebut diteliti tentang Hubungan Tingkat Pengetahuan Masyarakat Tentang Demam Berdarah Dengue dengan Perilaku Pencegahan Demam Berdarah Dengue di Wilayah Kerja Puskesmas Wonosalam 1 Kecamatan Wonosalam Kabupaten Demak. Data dianalisa dengan metode Cross Sectional dengan hasil sebesar 0,000 menunjukkan hasil yang sama bahwa tingkat pengetahuan memiliki hubungan yang signifikan dengan perilaku pencegahan demam berdarah dengue di wilayah kerja Puskesmas Wonosalam 1 Kecamatan Wonosalam Kabupaten Demak.

\section{KESIMPULAN}

Berdasarkan uraian diatas dapat disimpulkan bahwa :

1. Tingkat pengetahuan warga tentang demam berdarah yang termasuk dalam kategori tinggi ada 36 responden $(54,5 \%)$ dan yang termasuk dalam kategori rendah ada 30 responden $(45,5 \%)$ dengan nilai rata-rata 27,77 termasuk kategori tinggi.

2. Upaya pencegahan demam berdarah yang termasuk dalam kategori baik ada 39 responden $(59,1 \%)$ dan yang termasuk dalam kategori kurang baik ada 27 responden $(40,9 \%)$ dengan nilai rata-rata 16,44 termasuk kategori baik.

3. Ada hubungan antara tingkat pengetahuan warga tentang demam berdarah dengan upaya pencegahan demam berdarah dengan hasil uji Chi Square didapatkan hasil $\mathrm{p}$ : 0,004 dengan $(p<0,05)$.

\section{SARAN}

3. Bagi Instansi Pemerintah/

Puskesmas

Agar dapat memberikan penyuluhan tentang bagaimana upaya pencegahan demam berdarah agar tidak ada warga yang terserang demam berdarah.

4. Bagi Petugas Kesehatan

Bagi petugas kesehatan sebaiknya memberikan penyuluhan secara rutin tentang demam berdarah dan pencegahannya, supaya semakin meningkat pengetahuan tentang demam berdarah.

5. Bagi Warga

Agar selalu menjaga lingkungan dan meningkatkan upaya pencegahan demam berdarah supaya terhindar dari penyakit demam berdarah.

\section{DAFTAR PUSTAKA}

Depkes RI, Ditjen PPM\&PLP. Demam Berdarah Dapat Dicegah dengan Pemberantasan Jentik Nyamuknya. Jakarta: Depkes RI, 2006.

Dinas Kesehatan Propinsi Jawa Tengah. Profil Kesehatan Provinsi Jawa Tengah Tahun 2006. Semarang: Dinkes Jateng, 2006.

Fitriani, Sinta. Promosi Kesehatan. Yogyakarta: Graha IImu, 2011. 
Hidayat, A. Azis Alimul. Metode Penelitian Keperawatan dan Teknik Analisis Data. Jakarta: Salemba Medika, 2008.

\section{- Metode Penelitian Keperawatan dan Teknik Analisis Data. Jakarta: Salemba Medika, 2009.}

Misnadiarly. Demam Berdarah Dengue: Ekstrak Daun Jambu Biji Bisa untuk Mengatasi DBD. Jakarta: Pustaka Populer Obor, 2009.

Ngastiyah. Perawatan Anak Sakit. Jakarta: EGC, 2005.

Notoatmojo, Soekidjo. Kesehatan Masyarakat IImu dan Seni. Jakarta: Rineka Cipta, 2011.

Nursalam, Rekawati, dan Sri Utami. Asuhan Keperawatan Bayi dan Anak. Jakarta: Salemba Medika, 2008.

Riwikdido, Handoko. Statistik Kesehatan: Belajar Mudah : Teknik Analisis Data dalam Penelitian Kesehatan (Plus Aplikasi Software SPSS).

Yogyakarta: Pustaka Rihama, 2009.

Sudoyo, Bambang, et al., ed. Buku Ajar IImu Penyakit Dalam. Jakarta: Fakultas Kedokteran Universitas Indonesia, 2007.

Suyanto. Metodologi dan Aplikasi Penelitian Keperawatan. Yogyakarta: Nuha Medika, 2011.

Wawan dan Dewi M. Pengetahuan Sikap dan Perilaku Manusia. Yogyakarta: Nuha Medika, 2010.
Aseanto. Gambaran Pengetahuan Sikap dan Perilaku Masyarakat Terhadap Penyakit Demam Berdarah Dengue (DBD) di Kelurahan Cikondang Wilayah Kerja Puskesmas Tipar Kota Sukabumi. 2006.

Mahardika, Wahyu. Hubungan Antara Perilaku Kesehatan dengan Kejadian Demam Berdarah Dengue (DBD) di Wilayah Kerja Puskesmas Cepiring Kecamatan Cepiring Kabupaten Kendal 2009.

\footnotetext{
1 Dosen AKPER Panti Kosala Surakarta

2 Dosen AKPER Panti Kosala Surakarta

3 Mahasiswa AKPER Panti Kosala Surakarta
} 